\title{
LACK OF MACRONUTRIENTS IN Eucalyptus urophylla S.T. Blake (Myrtaceae) SEEDLINGS AFFECTS FEED AND DEVELOPMENT OF Podisus nigrispinus (Hemiptera: Pentatomidae)
}

\author{
DEFICIENNCIA DE MACRONUTRIENTES EM MUDAS DE Eucalyptus urophylla S.T. \\ Blake (Myrtaceae) AFETAM A ALIMENTAÇÃO E O DESENVOLVIMENTO DE \\ Podisus nigrispinus (Hemiptera: Pentatomidae)
}

\begin{abstract}
Estela Rosana Durães VIEIRA ${ }^{1,2}$; Enilson de Barros SILVA ${ }^{3}$; Marcus Alvarenga SOARES ${ }^{4}$; Sebastião Lourenço ASSIS JÚNIOR ${ }^{5}$; Gabriel Alves BARROSO ${ }^{6}$; Pedro Guilherme LEMES $^{7}$

1. Doutoranda em Ciências Florestais, Universidade Federal dos Vales do Jequitinhonha e Mucurí - UFVJM, Diamantina, MG, Brasil;

2. Professora, Mestre, Instituto Federal do Amazonas - IFAM, Lábrea, AM, Brasil. estela.duraes@ gmail.com; 3. Professor, Doutor, Departamento de Agronomia, UFVJM, Diamantina, MG, Brasil; 4. Professor, Doutor, Departamento de Agronomia, UFVJM,

Diamantina, MG, Brasil; 5. Professor, Doutor, Departamento de Engenharia Florestal, UFVJM. Diamantina, MG, Brasil; 6. Engenheiro Agrônomo, Técnico de Laboratório, Departamento de Zootecnia, UFVJM; 7. Professor, Doutor, Instituto de Ciências Agrárias, Universidade Federal de Minas Gerais -UFMG, Montes Claros, MG, Brasil.
\end{abstract}

\begin{abstract}
Several studies have reported the importance of phytophagy in the history of life from predator stinkbugs. However, knowledge of the nutrients acquired by these insects, from plant materials, is scarce. The phytophagy studies of zoophytophagous predators benefit biological control programs, making them more effective, since the best resources may be offered to these insects, increasing the potential for predation and, thus obtaining, success in pest control. Thus, this study investigated the development and zoophytophagy of predator Podisus nigrispinus (Dallas) (Hemiptera: Pentatomidae) in eucalyptus seedlings, deficient in macronutrients. The experiment was conducted in a greenhouse and the treatments consisted of individual nitrogen omission, phosphorus, potassium, calcium, magnesium and sulfur nutrient solution, where the eucalyptus seedlings were being conducted. The pupae of Tenebrio molitor L. (Coleoptera: Teneobridae) were offered ad libitum. The results of this experiment demonstrated the importance of nutrition in plants for the development and predation of $P$. nigrispinus. The plants deficient in nitrogen and magnesium reduce the predation efficiency of this zoophytophagous. The omission of calcium, magnesium and sulfur adversely affected the development of this insect predator, extending its immature stages. The proper nutritional balance of the plants is essential for the success in biological control programs that use zoophytophagous predators.
\end{abstract}

KEYWORDS: Biological Control. Plant Nutrition. Zoophytophagy.

\section{INTRODUCTION}

Predator stinkbugs belonging to the subfamily Asopinae (Hemiptera: Pentatomidae) are an alternative for the management of agricultural and forest pests (PEREIRA et al., 2010). These insects occur naturally in different crops and feed on a variety of insects (PIRES et al., 2015).

Podisus nigrispinus (DALLAS, 1851) is an important predator of this subfamily, feeding on larvae and adults of more than 30 species of Lepidoptera defoliators (RODRIGUES et al., 2008; ZANUNCIO et al., 2014). Brazilian forestry companies have been using $P$. nigrispinus and other Asopinae predators on the management of defoliating caterpillars on eucalyptus plantations to reduce the use of pesticides (DE BORTOLI et al., 2011; HOLTZ et al., 2011; PIRES et al., 2015).

These bugs exhibit five larval stages until become adults. They have carnivorous feeding habits, but may use their prey host plants as a supplement in their diet (COELHO et al., 2009;
EVANGELISTA JÚNIOR et al., 2004). The phytophagy may promote the maintenance of these natural enemies in the field, regardless of the presence of the pest (HOLTZ et al., 2011). These insects reduce their nymphal period, increase their weight as adults, longevity, and improve the predation efficiency and performance in reproduction by feeding on plant materials (ARMER et al., 1998; ASSIS JÚNIOR et al., 1998; EVANGELISTA et al., 2004; HOLTZ et al., 2011; LEMOS et al., 2010; ZANUNCIO et al., 2000).

Studies of phytophagy on predator stinkbugs have shown the importance of plant origin food in their lives (EUBANKS; DENNO, 1999), but the knowledge about the role of nutrients that are acquired on plants and prey to these insects is scarce. It is important to know these nutrients and their importance for the development and behavior of predators to make most effective biological control programs (COELHO et al., 2009).

The objective of this study was to assess the effect of the omission of the macronutrients: 
nitrogen, phosphorus, potassium, calcium, magnesium and sulfur, in eucalyptus seedlings in the development time and predation rate of the predator stinkbug $P$. nigrispinus.

\section{MATERIAL AND METHODS}

The experiment was conducted in a greenhouse at Universidade Federal dos Vales do Jequitinhonha e Mucuri (UFVJM), in Diamantina,

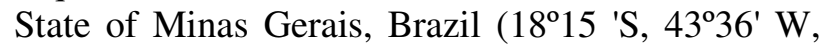
$1,400 \mathrm{~m}$ above sea level). The temperature and average relative humidity at the greenhouse were $26.6{ }^{\circ} \mathrm{C}$ and $46 \%$, respectively.

Seedlings of Eucalyptus urophylla S. T. Blake (Myrtaceae) with 45 days provided by the Company Aperam BioEnergia (Minas Gerais, Brazil) were used. The plants had similar shoot and root system, with height and average diameter of $34.4 \pm 1.2 \mathrm{~cm}$ and $0.19 \pm 0.4 \mathrm{~cm}$, respectively. The roots were rinsed in water and kept in deionized water for 15 days, to reduce the fertilization excess of clonal nursery. The seedlings were placed in the center of circular polystyrene dishes $(2 \mathrm{~cm}$ thick) and placed in plastic pots with $4.5 \mathrm{~L}$ of nutrient solution. The experiment was conducted in hydroponic system with aeration by compressed air and nutrient solution (CLARK, 1975), prepared with pure chemical reagents: ammonium nitrate, phosphoric acid, potassium chloride, anhydrous calcium chloride, magnesium chloride, sodium sulfate, boric acid, copper chloride, iron chloride, manganese chloride, zinc chloride, sodium molybdate, which were replenished weekly. The seedlings were acclimated in hydroponic condition with the concentrations used in the nutrient solution gradually increased every week $(25,50$ and $75 \%)$ until it reaches a concentration of $100 \%$ (CARVALHO NETO et al., 2011). The pH was adjusted to 5.5 on each concentration change interval. The determination of the levels of macronutrients was performed (MALAVOLTA et al., 1997).

Eggs of $P$. nigrispinus were obtained from a rearing at Biological Control Laboratory of UFVJM, $\left(25 \pm 2^{\circ} \mathrm{C}, 70 \pm 10 \%\right.$ relative humidity and photoperiod of 12 hours). One hundred eggs were placed in Petri dishes with moistened cotton attached to the lid and kept in a room with the same conditions. A total of 70 nymphs hatched from the eggs, and one day old, were randomly chosen and transferred to seven Petri dishes, in groups of 10, which were fed only with distilled water, until they reach the second instar. Two Tenebrio molitor L. (Coleoptera: Tenebrionidae) pupae were placed in each Petri dishes containing nymphs of this stage, when they start predation (MENEZES et al., 2014). The pupae of T. molitor were reared feeding on wheat bran and pieces of chayote.

Five of the ten nymphs of the predator were chosen randomly when they reached the third instar and were transferred for organza bags $(30 \times 15 \mathrm{~cm})$ wrapped around eucalyptus seedlings inside the greenhouse.

The influence of the absence of each macronutrient in development time and predation rate of $P$. nigrispinus on $T$. molitor pupae was evaluated. We used a completely randomized design, with seven treatments and five repetitions ( $N$ $=35)$. Each replication was a seedling of eucalyptus containing five nymphs. The treatments were $\mathrm{T} 1=$ nitrogen omission $(\mathrm{N})$; $\mathrm{T} 2=$ phosphorus omission $(\mathrm{P}), \mathrm{T} 3=$ potassium omission $(\mathrm{K}) ; \mathrm{T} 4=$ calcium omission $(\mathrm{Ca})$; T5 = magnesium omission $(\mathrm{Mg})$; T6 $=$ sulfur omission $(\mathrm{S}) ; \mathrm{T} 7=$ control $(\mathrm{CON})$ with macro and micronutrients of the nutrient solution of Clark (1975).

The first symptoms of nutritional deficiency in the eucalyptus seedlings were observed with 60 days after the beginning of the experiment. At this time, the predator third instar nymphs were placed on the seedlings. The development of the nymphs was daily assessed until they reach adulthood.

Three T. molitor pupae, one day old, were offered to each group of five nymphs on eucalyptus seedlings to assess the food intake of the predator. The pupae were weighed on analytical balance and placed in the organza bags, with the predator. Another weighing was made after 72 hours to obtain the amount $(\mathrm{g})$ of food ingested by $P$. nigrispinus. The average of three consumption evaluations of $T$. molitor pupae was performed for each stage of the predator. Five samples with three pupae were weighed and kept on the same conditions to determine the amount of water lost by the prey during 72 hours. After this time the pupae were weighed again and the average water lost subtracted from food consumption data.

Development data were submitted to analysis of variance and then to Dunnett test at 5\% probability, compared to the control treatment. Data on predation were subjected to analysis of variance and then to Scott \& Knott test at 5\%.

Nutritional analysis of pupae used for feeding $P$. nigrispinus was performed to identify the nutrients present in this prey. Five samples of $T$. molitor were used, containing three pupae, with average weight of $60 \pm 4 \mathrm{mg}$ each, which were dried in an oven at $65^{\circ} \mathrm{C}$ until reach constant weight (about 48 hours). 
The determination of nitrogen on the samples was performed by sulfuric digestion, with Kjeldahl analytical procedure (MALAVOLTA et al., 1997). For the other nutrients, it was used an energy dispersive $\mathrm{x}$-ray fluorescence spectrometer.

\section{RESULTS}

Lack of macronutrients in eucalyptus seedlings and food consumption by Podisus nigrispinus
The nitrogen and magnesium omission in the nutrient solution reduced the predator feeding in pupae of T. molitor (Table 1). The average total consumption of pupae, for each group of five predatory stinkbugs, was $100 \mathrm{mg}$ on the control and, $38 \mathrm{mg}$ and $72 \mathrm{mg}$ for omission of $\mathrm{N}$ and $\mathrm{Mg}$, respectively. The omission of $\mathrm{P}, \mathrm{K}, \mathrm{Ca}, \mathrm{S}$ did not affect the feeding of the nymphs and the average total consumption ranged from $96 \mathrm{mg}$ to $106 \mathrm{mg}$. A progressive increase in predation rate was observed in these treatments.

Table 1. Podisus nigrispinus (Dallas, 1851) (Hemiptera: Pentatomidae) feeding on Tenebrio molitor L. (Coleoptera: Tenebrionidae) pupae in Eucalyptus urophylla (Myrtaceae) seedlings cultivated with the omission of macronutrients.

\begin{tabular}{|c|c|c|c|c|c|c|c|c|}
\hline \multirow[t]{2}{*}{ Treatment } & \multicolumn{8}{|c|}{$\begin{array}{l}\text { Average consumption (mg) of Tenebrio molitor pupae for each immature stage of } \\
\text { Podisus nigrispinus }\end{array}$} \\
\hline & \multicolumn{2}{|l|}{ Instar III } & \multicolumn{2}{|c|}{ Instar IV } & \multicolumn{2}{|c|}{ Instar V } & \multicolumn{2}{|c|}{ Average } \\
\hline Control & 0,031 & $\mathrm{a}$ & 0,104 & $\mathrm{a}$ & 0,165 & $\mathrm{a}$ & 0,100 & $\mathrm{a}$ \\
\hline N Omission & 0,035 & $\mathrm{a}$ & 0,034 & $\mathrm{~b}$ & 0,044 & b & 0,038 & $\mathrm{~b}$ \\
\hline P Omission & 0,038 & $\mathrm{a}$ & 0,108 & $\mathrm{a}$ & 0,159 & $\mathrm{a}$ & 0,102 & $\mathrm{a}$ \\
\hline K Omission & 0,061 & $\mathrm{a}$ & 0,129 & $\mathrm{a}$ & 0,129 & $\mathrm{a}$ & 0,106 & $\mathrm{a}$ \\
\hline Ca Omission & 0,037 & $\mathrm{a}$ & 0,101 & $\mathrm{a}$ & 0,149 & $\mathrm{a}$ & 0,096 & $\mathrm{a}$ \\
\hline Mg Omission & 0,041 & $\mathrm{a}$ & 0,096 & $\mathrm{a}$ & 0,077 & b & 0,072 & $\mathrm{~b}$ \\
\hline S Omission & 0,036 & $\mathrm{a}$ & 0,097 & $\mathrm{a}$ & 0,174 & $\mathrm{a}$ & 0,102 & $\mathrm{a}$ \\
\hline CV (\%) & 48,04 & & 28,75 & & 26,94 & & 30,01 & \\
\hline
\end{tabular}

Means followed by the same letter in the column do not differ between each variable evaluated by the Scott \& Knott test at $5 \%$.

There was no positive correlation between advance in the development and increased predation rate for all instars changes in treatments where the $\mathrm{Mg}$ and $\mathrm{N}$ were omitted, but the insects reached adulthood. The consumption of prey in the fourth instar was lower for the nitrogen omission treatment when compared to other treatments. In the fifth instar it was observed that with the omission of nitrogen and magnesium the prey consumption was lower when compared to other treatments.
Lack of macronutrients in eucalyptus seedlings and the development of Podisus nigrispinus

The nymphs of the predator in the third instar in plants lacking of calcium, took 2.6 days more to change to the next stage, compared to the control (Figure 1 and Table 2). In the fourth stage, it was found that treatments lacking on $\mathrm{N}, \mathrm{P}$ and $\mathrm{S}$ increased nymphal period on $2.93 ; 3.73$ and 3.02 days, respectively, compared to control. The development of the fifth stage, the treatments that were lacking $\mathrm{P}, \mathrm{Mg}$ and $\mathrm{S}$, increased by $0.49 ; 4.25$ and 3.62 days, respectively, compared to the control.

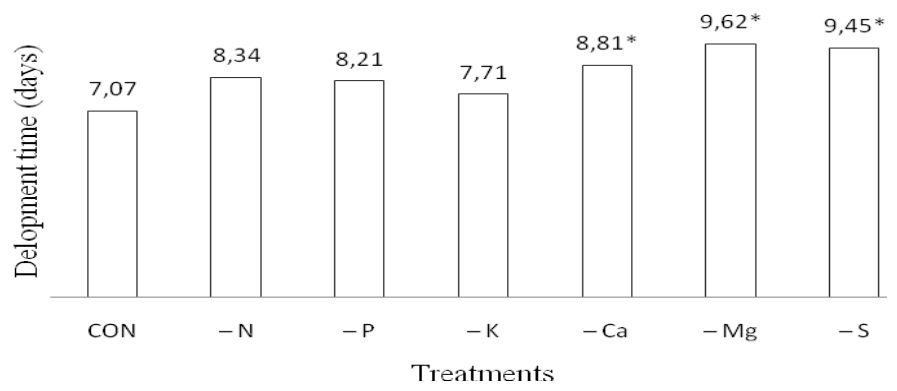

Figure 1. Average time (days) of development in stages III, IV and V of Podisus nigrispinus (Dallas, 1851) (Hemiptera: Pentatomidae) on eucalyptus leaves in different fertilization treatments: CON (control); -N (N omission); -P (P omission); -K (K omission); -ca (Ca omission); $\mathrm{Mg}$ (Mg omission) and $\mathrm{S}$ (S omission). $* \mathrm{p}<0.05$ compared to control treatment by Dunnett's test. 
Table 2. Stages development time (days) of Podisus nigrispinus (Dallas, 1851) (Hemiptera: Pentatomidae) in Eucalyptus urophylla (Myrtaceae) leaves, cultivated with the omission of macronutrients.

\begin{tabular}{|c|c|c|c|c|c|c|c|}
\hline Stage & Control & $\mathrm{N}$ & $\mathrm{P}$ & $\mathrm{K}$ & $\mathrm{Ca}$ & $\mathrm{Mg}$ & $\mathrm{S}$ \\
\hline III & 7,76 & 9,20 & 6,80 & 8,40 & $10,36^{*}$ & 9,44 & 8,92 \\
\hline IV & 5,94 & $8,87 *$ & $9,67 *$ & 5,49 & 8,59 & 8,36 & $8,96^{*}$ \\
\hline V & 7,51 & 4,99 & $8,00 *$ & 9,26 & 6,60 & $11,76^{*}$ & $11,13^{*}$ \\
\hline
\end{tabular}

$* \mathrm{p}<0.05$ compared to control treatment by Dunnett's test.

\section{Nutritional analysis of $T$. molitor used to feed $P$. nigrispinus}

All macronutrients were found in T. molitor pupae, except magnesium (Figure 2).

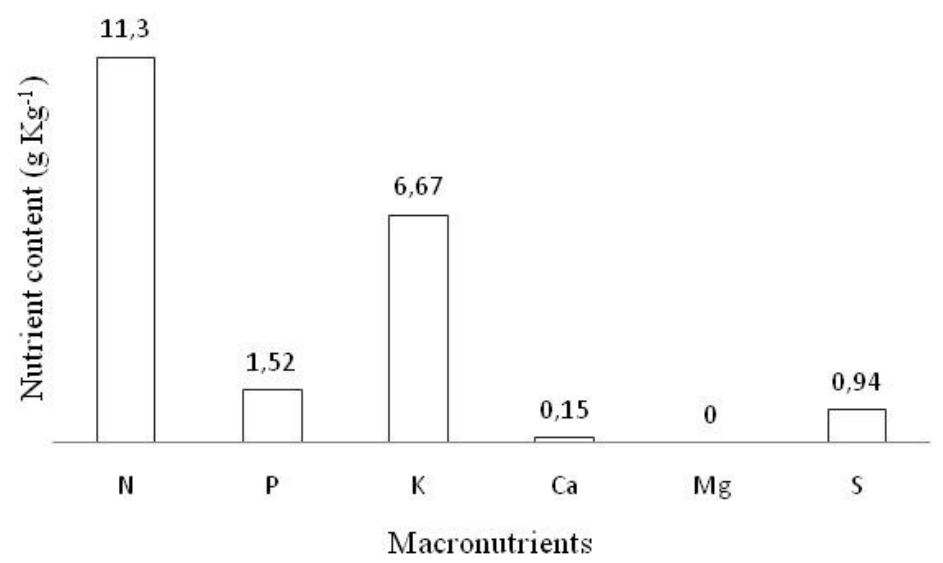

Figure 2. Macronutrients in Tenebrio molitor (Coleoptera: Tenebrionidae) pupae.

\section{DISCUSSION}

The need of $P$. nigrispinus to feed on plants was observed. Plants provide nutrients that are essential to these insects and are not available in their preys (HAMDI et al., 2013; VANKOSKY et al., 2015; ZANUNCIO et al., 2008).

It is not known the exact role the Mg plays in insect nutrition (CLARK, 2012). However, as shown here, it was observed that the lack of $\mathrm{Mg}$ in plants decreases the feed rate of the predators (CLANCY; KING, 1993).

It is clear the need of nitrogen from the plant food source for phytophagous insects due to the central role this element plays in metabolic processes, cell structure and genetic code (PIZZAMIGLIO, 1991).

The zoophytophagous Dicyphus hesperus Knight (Hemiptera: Miridae) feed more on prey that have high nitrogen concentrations in comparison to ones with low concentrations (VANKOSKY et al., 2015). In this work, P. nigrispinus decreased his predation, compared to control treatment, even preys having large amounts of nitrogen. This may be due the fact of zoophytophagous needs of the water obtained through plant food source to perform the predation (GILLESPIE, 2000; McGREGOR, 2000). Thus, the lack of nitrogen in plants discourages the phytophagy and as a consequence the insects got less water, compromising in obtaining prey. The longest development time of $P$. nigrispinus due the lack of sulfur may be associated with the synthesis of juvenile hormone, essential for the molt. This nutrient is a structural component of acetyl-CoA, which gives rise to Acetoacetil CoA, precursor of key enzymes to the synthesis of juvenile hormone (KLOWNDEN, 2007). It is possible that the lack of $S$ in plants changed the synthesis of juvenile hormone, delaying the molting in the predator nymphs, making them staying longer in the fourth instar.

Lack of $\mathrm{Ca}$ also delayed the development of the predator, probably due the fact that it is required for the production of ecdysone, another hormone involved in molting. The lack of calcium prevents the action of the HPTT hormone when there is an influx of $\mathrm{Ca}^{2+}$ into cells of prothoracic gland (KLOWNDEN, 2007). Thus, the cAMP (cyclic adenosine monophosphate) concentration will not elevate in the absence of these ions. The cAMP 
activates protein kinase and the consequence of the lack of $\mathrm{Ca}$ is the deficiency of the production and release of ecdysone (MATTSON; SPAZIANI, 1986; RUPPERT et al., 2005).

The extension of nymphal stage time due the lack of those nutrients is not interesting for biological control programs (MENEZES et al, 2014). These programs search for insects that reaching the reproductive phase quickly. This study showed that nutritional balance of the host plant is essential for good development and predation rate of $P$. nigrispinus.

\section{CONCLUSIONS}

The omission of macronutrients may be a disadvantage to $P$. nigrispinus.
A proper nutrient balance in plants is important for biological control programs and eucalyptus plantations should be kept in a good nutritional state in order to promote these predators.

\section{ACKNOWLEDGEMENTS}

This research received funding from CAPES (Coordenação de Aperfeiçoamento de Pessoal de Nível Superior), FAPEMIG (Fundação de Amparo à Pesquisa do Estado de Minas Gerais) and CNPq (Conselho Nacional do Desenvolvimento Científico e Tecnológico).

RESUMO: Diversos estudos têm relatado a importância da fitofagia na história de vida dos percevejos predadores. Porém, não se conhece quais são os nutrientes adquiridos por estes insetos nos materiais vegetais. Sabe-se que a fitofagia realizada pelos predadores zoofitófagos beneficia os programas de controle biológico, tornando-os mais eficazes, e que as plantas oferecem recursos que poderão aumentar o potencial de predação, garantindo o sucesso no controle de pragas. Deste modo, este trabalho investigou o consumo alimentar e desenvolvimento do percevejo Podisus nigrispinus (Dallas) (Hemiptera: Pentatomidae), sob mudas de eucalipto, submetidas à solução nutritiva com omissão de macronutrientes. $\mathrm{O}$ experimento foi realizado em casa de vegetação e os tratamentos consistiram na omissão individual de nitrogênio, fósforo, potássio, cálcio, magnésio e enxofre da solução nutritiva, onde as mudas de eucalipto se desenvolveram. Pupas de Tenebrio molitor L. (Coleoptera: Teneobridae), foram oferecidas ad libitum. Os resultados deste experimento comprovaram a importância da complementação nutricional em plantas para o consumo alimentar e desenvolvimento do $P$. nigrispinus. A alimentação nas plantas em que o nitrogênio e magnésio foram omitidos diminuiu o consumo de biomassa animal das presas deste zoofitófago. E a omissão de cálcio, magnésio e enxofre afetou, negativamente, o desenvolvimento deste percevejo predador, prolongando seu estádio imaturo. O balanço nutricional adequado das plantas é fundamental para obter sucesso em programas de controle biológico em que se utilizam predadores zoofitófagos.

PALAVRAS-CHAVE: Controle Biológico. Nutrição de plantas. Zoofitófagos.

\section{REFERENCES}

ARMER, C. A.; WIEDENMANN, R. N.; BUSH, D. R. Plant feeding site selection on soybean by the facultative lyphytophagous predator Orius insidiosus. Entomologia Experimentalis et Applicata, Netherlands, v. 86, s/n, p. 109-118, 1998.

ASSIS JUNIOR, S. L.; ZANUNCIO, T. V.; SANTOS, G. P.; ZANUNCIO, J. C. Efeito da suplementação de folhas de Eucalyptus urophylla no desenvolvimento e reprodução do predador Supputius cincticeps (Stal) (Heteroptera: Pentatomidae). Anais da Sociedade Entomológica do Brasil, Londrina, v. 27, n. 2, p. 245-253, 1998. https://doi.org/10.1590/S0301-80591998000200011

CARVALHO NETO, J. P.; SILVA, E. B.; SANTANA, R. C.; GRAZZIOTTI, P. H. Effect of NPK fertilization on production and leaf nutrient content of eucalyptus minicuttings in nutrient solution. Revista Brasileira de Ciências do Solo, Viçosa, v. 35, n. 1, p. 249-254, 2011.

CLANCY, K. M.; KING, R. M. Defining the western spruce budworm's nutritional niche with response surface methodology. Ecology, Washington, v. 74, n. 2, p. 442-454, 1993. https://doi.org/10.2307/1939306 
CLARK, R. B. Characterization of phosphatase of intact maize roots. Journal of Agricultural and Food Chemistry, Washington, v. 23, n. 3, p. 458-460, 1975. https://doi.org/10.1021/jf60199a002

CLARK, K. E.; HARTLEY, S. E.; BRENNAN, R. M.; MACKENZIE, K.; JOHNSON, S. N. Investigating preference-performance relationships in aboveground-belowground life cycles: a laboratory and field study with the vine weevil (Otiorhynchus sulcatus). Bulletin of Entomological Research, Cambridge, V. 102, n. 1, p. 63-70, 2012. https://doi.org/10.1017/S0007485311000368

COELHO, R. R.; VEIGA, A. F. S. L.; TORRES, J. B. Feeding preference and performance of Brontocorìs tabidus (Signoret) (Hemiptera, P entatomidae) among host plants. Revista Brasileira de Entomologia, São Paulo, v. 53, n. 3 p. 475-481. 2009. https://doi.org/10.1590/S0085-56262009000300025

DE BORTOLI, S. A.; OTUKA, A. K.; VACARI, A. M.; MARTINS, M. I. E. G.; VOLPE, H. X. L. Comparative biology and production costs of Podisus nigrispinus (Hemiptera: Pentatomidae) when fed different types of prey. Biological Control, Orlando, v. 58, n. 2, p. 127-132, 2011.

https://doi.org/10.1016/j.biocontrol.2011.04.011

EUBANKS, M. D.; DENNO, R. F. The ecological consequences of variation in plants and prey for an omnivorous insect. Ecology, Washington, v. 80, n. 4, p. 1253-1266, 1999. https://doi.org/10.1890/00129658(1999)080[1253:TECOVI]2.0.CO;2

EVANGELISTA JÚNIOR, W. S. E.; GONDIM JÚNIOR, M. G. C.; TORRES, J. B.; MARQUES, E. J. Fitofagia de Podisus nigrispinus em algodoeiro e plantas daninhas. Pesquisa Agropecuaria Brasileira, Brasília, v. 39, n. 5, p. 413-420, 2004. https://doi.org/10.1590/S0100-204X2004000500002

GILLESPIE, D. R.; MCGREGOR, R. R. The functions of plant feeding in the omnivorous predator Dicyphus hesperus: water places limits on predation. Ecological Entomology, London, v. 25, n. 4, p. 380-386, 2000. https://doi.org/10.1046/j.1365-2311.2000.00285.x

HAMDI, F.; CHADOEUF, J.; BONATO, O. Functional relationships between plant feeding and prey feeding for a zoophytophagous bug. Physiological Entomology, London, v. 38, n. 3, p. 241-245, 2013. https://doi.org/10.1111/phen.12028

HOLTZ, A. M.; ALMEIDA, G. D.; FADINI, M. A. M.; ZANUNCIO, J. C.; ZANUNCIO JÚNIOR, J. S.; ANDRADE, G. S. Phytophagy on eucalyptus plants increases the development and reproduction of the predator Podisus nigrispinus Dallas, 1851 (Hemiptera, Pentatomidae). Acta Scientiarum. Agronomy, Maringá, v. 33, n. 2, p. 231-235, 2011.

KLOWNDEN, M. J. Physiological systems in insects, New York, 2007, 3. ed., 2013, 696 p.

LEMOS, W. P.; ZANUNCIO, J. C.; RAMALHO, F. S.; ZANUNCIO, V. V.; SERRÃO, J. E. Herbivory affects ovarian development in the zoophytophagous predator Brontocoris tabidus (Heteroptera, Pentatomidae). Journal of Pest Science, Heidelberg, v. 83, n. 2, p. 69-76, 2010. https://doi.org/10.1007/s10340-009-0271-z

MALAVOLTA, E.; VITTI, G. C.; OLIVEIRA, S. A. Avaliação do estado nutricional das plantas: princípios e aplicações. 2.ed. Piracicaba: POTAFÓS, 1997. 319 p.

MATTSON, M. P.; SPAZIANI, E. Regulation of crab Y-organ steroidogenesis in vitro: evidence that ecdysteroid production increases through activation of cAMP-phosphodiesterase by calcium-calmodulin.

Molecular and Cellular Endocrinology, London, v. 48, n. 2-3, p. 135-51, 1986. https://doi.org/10.1016/03037207(86)90036-5 
MENEZES, C. W. G.; CAMILO, S. S.; FONSECA, A. J.; ASSIS JÚNIOR, S. L. B; DIEGO, F.; SOARES, M. A. A dieta alimentar da presa Tenebrio molitor (Coleoptera: Tenebrionidae) pode afetar o desenvolvimento do predador Podisus nigrispinus (Heteroptera: Pentatomidae)? Arquivos do Instituto Biológico, São Paulo, v. 81, n. 3, p. 250-256, 2014. https://doi.org/10.1590/1808-1657001212012

PEREIRA, A. I. A.; RAMALHO, F. S.; RODRIGUES, K. C. V.; MALAQUIAS, J. B.; SOUZA, J.; SILVA, V.; ZANUNCIO, J. C. Food Extraction by the Males of Podisus nigrispinus (Dallas) (Hemiptera: Pentatomidae) from Cotton Leaf worm Larvae. Brazilian Archives of Biology and Technology, Curitiba, v. 53, n. 5, p. 1027 1035, 2010. https://doi.org/10.1590/S1516-89132010000500004

PIRES, E. M.; SOARES, M. A.; NOGUEIRA, R. M.; ZANUNCIO, J. C.; MOREIRA, P. S. A.; OLIVEIRA, M. A. Seven decades of studies with Asopinae predators in Brazil. Bioscience Journal, Uberlândia, v. 31, n. 5, p. 1530-1549, 2015. https://doi.org/10.14393/BJ-v31n5a2015-27335

PIZZAMIGLIO, M. A. Ecologia das interações inseto/planta, in: PANIZZI, A. R.; PARRA, J. R. Ecologia nutricional de insetos e suas implicações no manejo de pragas. São Paulo: Manole, 1991, p. 101-129.

RODRIGUES, A. R. S.; SERRÃO, J. E.; TEIXEIRA, V. W.; TORRES, J. B.; TEIXEIRA, A. A. Spermatogenesis, changes in reproductive structures, and time constraint associated with insemination in Podisus nigrispinus. Journal of Insect Physiology, London, v. 54, n. 12, p. 1543-1551, 2008. https://doi.org/10.1016/j.jinsphys.2008.09.003

RUPPERT, E. E.; FOX, R. S.; BARNES, R. D. Zoologia dos vertebrados: uma abordagem funcionalevolutiva. 7. ed. São Paulo: Roca, 2005. 1145 p.

VANKOSKY, M. A.; VANLAERHOVEN, S. L. Plant and prey quality interact to influence the foraging behaviour of an omnivorous insect, Dicyphus hesperus. Animal Behaviour, Washington, v. 8, s/n, p. 109-116, 2015.

ZANUNCIO, J. C.; ZANUNCIO, T. V.; GUEDES, R. N. C.; RAMALHO, F. S. Effect of feeding on three Eucalyptus species on the development of Brontocoris tabidus (Het.:Pentatomidae) fed with Tenebrio molitor (Col.:Tenebrionidae). Biocontrol Science and Technology, London, v. 10, n. 4, p. 443-450, 2000. https://doi.org/10.1080/09583150050115025

ZANUNCIO, J. C.; SILVA, C. A. D.; LIMA, E. R. L.; PEREIRA, F. P.; RAMALHO, F. S.; SERRÃO, J. E. Predation rate of Spodoptera frugiperda (Lepidoptera: Noctuidae) larvae with and without defense by Podisus nigrispinus (Heteroptera: Pentatomidae). Brazilian Archives of Biology and Technology, Curitiba, v. 51, n. 1, p. 121-125, 2008. https://doi.org/10.1590/S1516-89132008000100015

ZANUNCIO, J. C.; TAVARES, W. S.; FERNANDES, B. V.; WILCKEN, C. F.; ZANUNCIO, T. V. Production and use of Heteroptera predators for the biological control of Eucalyptus pests in Brazil. Ekoloji, Izmir, v. 23, n. 91, p. 98-104, 2014. https://doi.org/10.5053/ekoloji.2014.9112 